\title{
MINIMIZING OF SCOUR DOWNSTREAM HYDRAULIC STRUCTURES USING SEMI - CIRCULAR SILL
}

\author{
Hitham Abdel Samad ${ }^{1}$, Helal Y. Esam ${ }^{2}$, Ibrahim S.A ${ }^{3}$, and Sobeih M.F
}

\begin{abstract}
Local scour downstream control structures may cause sevier damage or complete failure to the control structures. Through this research, an experimental study was conducted using semi-circular sill. The suggested shape is easy to be used as an extra element to existing structures to minimize the scour downstream control structures. A hundred eighty nine experimental runs were carried out considering various heights and positions of sill with different flow conditions. A case of flat floor without sill was included as original case and to be compared with the cases using sill. The influence of using the semi-circular sill on the scour hole dimensions was evaluated. Obtained results were analyzed and graphically presented.
\end{abstract}

ظاهرة النحر خلف منشك التحكم قد تسب الضرر أو النهيار كلمل للمشالت. في هذا البحث لجُريت درلسة معملية بلستخدل

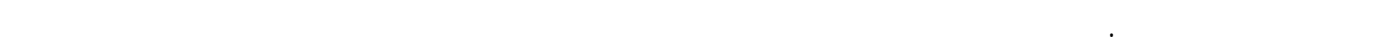

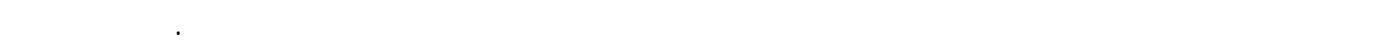

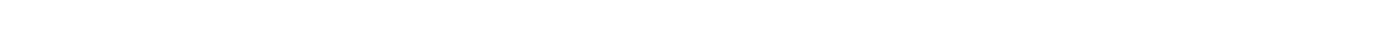

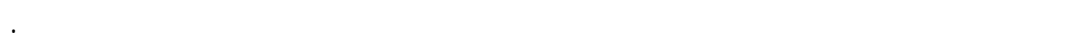

Keywords: Hydraulic structures, Hydraulic jump, Scour holes,semi- circular sill, Physical model.

${ }^{1}$ General Manager, Ministry of Water Resources and Irrigation, Egypt

${ }^{2}$ Assist. Prof, Civil Engineering Dept, Faculty of Engineering, Menofiya University.

${ }^{3}$ Assoc. Prof, Hydraulics Research Institute, National Water Research Center, Egypt

${ }^{4}$ Professor of Hydraulics, Civil Engineering Dept, Faculty of Eng., Menofiya University. 


\section{INTRODUCTION}

Flow over spillways or underneath gates has a tremendous amount of potential energy, which is converted into kinetic energy downstream the control structures. This energy should be dissipated to prevent the possibility of excessive scouring downstream the river bed, minimize bed erosion and the undermining of the structures, which endanger the structure safety.

Local scour downstream control structures is a sevier problem as several hydraulic structures were failed as a result of scouring activities behind the toe of these structures. Sill installed in aprons principally to stabilize the formation of the jump and increase the turbulence, thereby assisting in the dissipation of energy. For low flow, sill help to compensate for a slight deficiency of tail water and for high flow, they help to deflect the flow away from the river bed. The employment of the sill may be helpful in reducing the tail water depth required and also in shortening the basin length. Sill should be used in the stilling basin even if they are not required to form a stable hydraulic jump, Edward (1959). Under initial operating conditions, however, the gates were opened much faster than the tail water could be build up, so that, there was a deficiency of tail water for hours. Sill prevented excessive erosion of the exit area during this period. Also, they help to ensure good hydraulic jump action for unbalanced spillway gate operation or submerged conditions occurring at discharges greater than those for which the stilling basin was designed. There are many types and shapes of baffles that have been used which have served their intended purpose. Because of many variables, no one solution may be applicable for all conditions. Bhowmik (1975) studied the effect of using baffle blocks with different inclination angles to the incoming flow on the scour hole characteristics. He found that, using baffle blocks normal to the flow direction gave good results. Pillai and Unny (1964) studied the effect of the vertex angle of the wedgeshaped baffle blocks on the drag force. They found that, the drag of the wedge- shaped baffle blocks increased as the vertex angle increase. Pillai (1966; 1969) studied the effect of using a wedge-shaped baffle blocks of vertex angle $120^{\circ}$ cut back at right angle. Good results were obtained for Froude number between 5 and 9 .

Many different baffle block shapes have been proposed studied by Bradly (1957), walter (1965), walter (1966), peterka (1978), El-Masry and sarhan (2000). Vischer and Hager (1995), El-Gamal (2001), and El-Masry (2001) discussed the baffle block parameters and summarized the following:-

- One row of blocks is used because the effect of the second row or staggered block rows is small relative to the first one,

- The optimum blocks front face is vertical and perpendicular to the approach flow, and

The present research is initiated according to the recommendations of the previous literature. The suggested sill has a semi-circular shape and assumed to be perpendicular to the flow. The proposed element is easy to be used as a pre-cast unit providing to the floor of the existing structures, in order to minimize the deformed scour hole.

\section{THEORETICAL ANALYSIS}

In this paper, to study the effect of the proposed semi-circular sill, the phenomenon was investigated experimentally with flat floor without any sill to use its results as a reference case to the case of floor with sill.

Referring to the model, the dimension describing the sill that was made of steel material are:-

- Semi-circular sill outer diameter, $D_{0}$ is kept constant,

- $\quad$ Sill thickness, $\mathrm{t}$ is not changed, and

- Sill height, $\mathrm{H}_{\mathrm{b}}$ is considered to be a variable to estimate the most suitable height $\left(\mathrm{H}_{\mathrm{b}}=0.017\right.$, $0.033,0.05$, and 0.067 , and $0.083 \mathrm{D}_{\mathrm{o}}$ )

To investigate the influence of sill location on the scour downstream the floor, their position is varied as $\left(\mathrm{L}_{\mathrm{b}} / \mathrm{L}_{\mathrm{f}}=0.2,0.4,0.6\right.$, and 0.8$)$. Adopted sill is therefore, of invariable shape but variable height and position.

\section{EXPERIMENTAL SET-UP}

Figure (1) shows the apparatus used in the present study. The main flume is $60 \mathrm{~cm}$ wide, $60 \mathrm{~cm}$ deep and $20 \mathrm{~m}$ long. The flume is constructed of bricks sealed with smooth cement mortar. The flume consists of head and tail tanks, main and by-pass channels. A centrifugal pump is used to supply water to the head tank from the ground sump. Water is controlled using a control valve installed on the pipe connected to the feeding pump. The head tank has a gravel box, which is used to provide an even flow distribution across the flume. The flow enters main channel through an inlet screen to absorb any water eddies. The main channel contains a pipe through box is made of wood material, the pipe is $10 \mathrm{~cm}$ diameter fixed in the center of box (as a culvert structure). Water depth $\mathrm{y} 1, \mathrm{y} 2$ and $\mathrm{Y}$ is measured with a precise vertical scale. The downstream bay is made of smooth cement-sand mortar overlaid on a $0.5 \mathrm{~m}$ layer of sand to prevent leakage, this bay is represented the solid floor and also, prepared for the 
sill fixation. The rear reach of the channel is filled with a $0.40 \mathrm{~m}$ deep layer of a uniform PVC material with $\mathrm{D}_{50}=2.5 \mathrm{~mm}$, and a specific weight of 1080 $\mathrm{kg} / \mathrm{m}^{3}$ in order to represent the movable bed(to give laboratory results relative to the small V, Qin lab.) Precise point gauge is installed to measure the bed level and the water depth. The gauge is mounted on carriage moving in the flow and the perpendicular directions. Downstream water depth is controlled using a tail gate and then, the water flowed to the bypass channel. The length of floor and sill dimensions is kept constant for all runs. Sill positions are changed from one position to other to reach the most suitable location to reduce scour.

\section{EXPERIMENTAL PROCEDURE}

To study the effect of using semi-circular sill, three discharges are considered $(\mathrm{Q}=15,21$, and 26 $\mathrm{Lit} / \mathrm{sec}$ ). For each discharge, the tail water depth is changed three times. Semi-circular sills are arranged in four position $\left(\mathrm{L}_{b} / \mathrm{L}_{\mathrm{f}}=0.2,0.4,0.6\right.$, and 0.8$)$. For each position, the sill height is changed five times $\left(\mathrm{H}_{\mathrm{b}} / \mathrm{D}_{\mathrm{o}}=0.017,0.033,0.05,0.067\right.$, and 0.0 .83$)$ to reach the best height that leads to minimize the scour hole. 189 runs were conducted including 9 runs without sill. These nine flat floor runs were considered as a reference case.

For each run, the backwater feeding is started first until its depth reaches higher than the required downstream water depth, and then, the upstream feeding is pumped. To adjust the tail water depth, the tail gate is screwed gradually until the considered depth is adjusted. After several trials, a two-hour period was selected as a constant time for all runs. After the running time, the run was stopped and the flume was drained and the expecting scouring area was recorded with a precise point gauge to monitor the bed topography on a grid $10 \mathrm{~cm} x 10 \mathrm{~cm}$. To estimate the maximum scour, a finer grid $5 \mathrm{~cm} \times 5 \mathrm{~cm}$ was sometimes used depending on the shape of the bed topography.

\section{RESULTS AND ANALYSIS}

5.1 Effect of Semi-circular sill on Hydraulic Jump Parameters

Although the length and the location of the hydraulic jump are not measured exactly in this research, but initial and sequent water depth of the hydraulic jump, are measured precisely, and the following may be concluded:-

- The sequent depth of hydraulic jump increases more than that the case of no sill, and

- In case of using sill, Less than one half of the initial specific energy is lost through the hydraulic jump.
Figures from 2 to 5 illustrate the relation between relative energy losses $\Delta \mathrm{E} / \mathrm{E}_{1}$, and $1 / \mathrm{F}_{\mathrm{r}}{ }^{2}$ with respect to the considered values of sill positions $\mathrm{L}_{\mathrm{b}} / \mathrm{L}_{\mathrm{f}}=$ $0.2,0.4,0.6$, and 0.8 . One can see that, for the considered flow conditions, the values of $\Delta \mathrm{E} / \mathrm{E}_{1}$ are less than 0.5 . This means that, the energy dissipated through the hydraulic jump is lower than half of the specific energy at the initial depth of the hydraulic jump.

For all considered arrangements of sill, increasing $\mathrm{H}_{\mathrm{b}} / \mathrm{D}_{\mathrm{o}}$, leads to decrease the ratio of $\Delta \mathrm{E} / \mathrm{E}_{1}$. This means that, increasing the sill heights decrease the hydraulic jump relative losses. It is evident that, the value of $\mathrm{L}_{\mathrm{b}} / \mathrm{L}_{\mathrm{f}}$ has not significant effect on the values of $\mathrm{y}_{2} / \mathrm{y}_{1}$

\subsection{Effect of Semi-circular Sill on Scour hole Parameters}

Results were grouped into dimensionless terms and the relationships were drawn to study the effect of these parameters on the scour hole dimensions $\left(D_{s}\right.$ and $\mathrm{L}_{\mathrm{s}}$ ).

Figure 6 illustrates the relation between $D_{s} / D_{s w}$ and $1 / \mathrm{F}_{\mathrm{r}}{ }^{2}$ with respect to the considered values of sill positions $\mathrm{L}_{\mathrm{b}} / \mathrm{L}_{\mathrm{f}}=0.2,0.4,0.6$, and 0.8 .

One can see that, for the considered flow conditions, using semi-circular sill reduces the depth of the scour hole compared to the depth of the flat floor without sill, $\mathrm{Ds} / \mathrm{D}_{\mathrm{sw}}<1$. For all considered arrangements of sill, for smaller values of $1 / \mathrm{F}_{\mathrm{r}}^{2}$ the values of $\mathrm{H}_{\mathrm{b}} / \mathrm{D}_{\mathrm{o}}$ have smaller influence on the $\mathrm{D}_{\mathrm{s}} / \mathrm{D}_{\mathrm{sw}}$ values.

It is evident that, the effect of changing the height of sill has small influence on the scour hole depth, as the ratio of $\mathrm{L}_{\mathrm{b}} / \mathrm{L}_{\mathrm{f}}$ increases. For $\mathrm{L}_{\mathrm{b}} / \mathrm{L}_{\mathrm{f}}=0.4$ and 0.8 , It is clear that, for most height of sill, increasing the ratio of $1 / \mathrm{F}_{\mathrm{r}}{ }^{2}$ decreases the relative depth of scour hole. For $\mathrm{L}_{\mathrm{b}} / \mathrm{L}_{\mathrm{f}}=0.4$ and 0.6 , for most heights of sill, increasing $1 / \mathrm{F}_{\mathrm{r}}^{2}$ decreases the relative depth of scour hole, Approximately, except for $1 / \mathrm{F}_{\mathrm{r}}{ }^{2}$ is 7.0 to 8.5 . The value of $\mathrm{H}_{\mathrm{b}} / \mathrm{D}_{\mathrm{o}}=0.017$ gives the higher values of $\mathrm{D}_{\mathrm{s}} / \mathrm{D}_{\mathrm{sw}}$.

To show the effect of sill positions on the length of scour hole, for the considered heights of semicircular sill, Figure 7 illustrates the relationship between the relative scour length $\mathrm{L}_{\mathrm{s}} / \mathrm{L}_{\mathrm{sw}}$ and $1 / \mathrm{F}_{\mathrm{r}}^{2}$. For the considered arrangements of sill with all tested values of $\mathrm{H}_{\mathrm{b}} / \mathrm{D}_{\mathrm{o}}$, the value of $\mathrm{L}_{\mathrm{s}} / \mathrm{L}_{\mathrm{sw}}$ decreases as $1 / \mathrm{F}_{\mathrm{r}}{ }^{2}$ increases, except for $\mathrm{L}_{\mathrm{b}} / \mathrm{L}_{\mathrm{f}}=0.8$, at $\mathrm{H}_{\mathrm{b}} / \mathrm{D}_{\mathrm{o}}=0.017$ and 0.667 .

The value of $\mathrm{H}_{\mathrm{b}} / \mathrm{D}_{\mathrm{o}}=0.083$ gives the smaller value of $\mathrm{L}_{\mathrm{s}} / \mathrm{L}_{\mathrm{sw}}$ and the value of $\mathrm{H}_{\mathrm{b}} / \mathrm{D}_{\mathrm{o}}=0.017$ gives the higher values of $\mathrm{L}_{\mathrm{s}} / \mathrm{L}_{\mathrm{sw}}$. The effect of $1 / \mathrm{F}_{\mathrm{r}}^{2}$ on the value of $\mathrm{L}_{\mathrm{s}} / \mathrm{L}_{\mathrm{sw}}$ is almost the same, approximately except the value of $\mathrm{L}_{\mathrm{b}} / \mathrm{L}_{\mathrm{f}}=0.6$ at $\mathrm{H}_{\mathrm{b}} / \mathrm{D}_{\mathrm{o}}=0.017$. 
It is worth to mention that, for all considered arrangements of sill with all tested values of $1 / \mathrm{F}_{\mathrm{r}}^{2}$ and $\mathrm{H}_{\mathrm{b}} / \mathrm{D}_{\mathrm{o}}$, increasing $\mathrm{H}_{\mathrm{b}} / \mathrm{D}_{\mathrm{o}}$ leads to decrease $\mathrm{L}_{\mathrm{s}} / \mathrm{L}_{\mathrm{sw}}$.

\section{CONCLUSIONS}

The results of the experimental study for minimizing the scour hole dimensions downstream control structure using a single row of semi-circular sill have been presented; the discussion and analysis of the results highlighted the following conclusions:

- All suggested sill arrangements reduce the maximum scour hole depth as well as the scour hole length, and move the maximum scour hole depth closer to the floor, where the values of $\mathrm{D}_{\mathrm{s}} / \mathrm{D}_{\mathrm{sw}}$ and $\mathrm{L}_{\mathrm{s}} / \mathrm{L}_{\mathrm{sw}}$ are less than 0.067 and 0.9 respectively.

- The effect of $\mathrm{H}_{\mathrm{b}} / \mathrm{D}_{\mathrm{o}}$ on the scour hole characteristics is more significant than that $\mathrm{L}_{\mathrm{b}} / \mathrm{L}_{\mathrm{f}}$.

- It is apparent that, increases of tail Froude number leads to slight decrease in maximum scour depth and length for all considered sill arrangements. Also, move the maximum scour depth location far away from the floor in the flow direction.

- Using the single line of semi-circular sill causes more reduction of maximum scour depth under all considered flow conditions. The most efficient case for $1 / \mathrm{F}_{\mathrm{r}}^{2}<6.5$ (using $\mathrm{H}_{\mathrm{b}} / \mathrm{D}_{\mathrm{o}}=0.067$ and $\mathrm{L}_{\mathrm{b}} / \mathrm{L}_{\mathrm{f}}=0.4$ ) produces reduction in scour hole depth ranged from $49 \%$ to $61 \%$, while for $1 / \mathrm{F}_{\mathrm{r}}^{2}>6.5$ (using $\mathrm{H}_{\mathrm{b}} / \mathrm{D}_{\mathrm{o}}=0.083$ and $\mathrm{L}_{\mathrm{b}} / \mathrm{L}_{\mathrm{f}}=0.4$ ) yields to reduction in scour hole depth ranged from $51 \%$ to $80 \%$.

- Using the single line of semi-circular sill offers more reduction of maximum scour length under all tested flow conditions. The most efficient case $\left(\mathrm{H}_{\mathrm{b}} / \mathrm{D}_{\mathrm{o}}=0.083\right.$ and $\left.\mathrm{L}_{\mathrm{b}} / \mathrm{L}_{\mathrm{f}}=0.4\right)$ yields to reduction in scour hole length ranged from $71 \%$ to $88 \%$.

- The hydraulic jump location is controlled on the stilling floor,

- Using the single line of semi-circular sill offers, Less than one half of the initial specific energy is lost through the hydraulic jump.

\section{NOTATION}

The following symbols were used through this research:

$B$ : Channel width (cm)

$b:$ Basin width $(\mathrm{cm})$

$D_{o}$ : Outer sill's diameter $(\mathrm{cm})$

$D_{s}$ : Maximum scour depth $(\mathrm{cm})$

$D_{s w}:$ Maximum scour depth without sill

$E_{1}$ : Specific energy at the initial water depth of a hydraulic jump
$E_{2}$ : Specific energy at the sequent water depth of a hydraulic jump

$\Delta E$ : Energy losses through a hydraulic jump

$F_{r}$ : Tail Froude Number

$g$ : Gravitational acceleration

$L_{f}:$ Floor length $(\mathrm{cm})$

$L_{s}$ : Maximum scour length

$L_{s w}$ : Maximum scour length in case of no sill

$L_{b}$ : Distance between sill and the face of the pipe (cm)

$H_{b}$ : Sill's height $(\mathrm{cm})$

$Q$ : Discharge (Lit/sec)

$V:$ Flow velocity at the tail water depth

$Y$ : Tail water depth (cm)

$y_{1}$ : Initial water depth of a hydraulic jump

$y_{2}$ : Sequent water depth of a hydraulic jump

$\rho$ : Density of the fluid

$\rho_{s}$ : Density of bed material

\section{ACKNOWLEDGMENTS}

This work was carried out at the Hydraulics Research Institute, National Water Research Center, Egypt. Authors gratefully acknowledge the collaboration and effort done by all staff members of the Institute.

\section{BIBLIOGRAPHY}

Aytac S. and Gunal, M. (2008) "Prediction of Scour downstream of Grad-Control Structures Using Neural Networks", Journal of Hydraulic Engineering, ASCE, Vol.10, PP. 0733-9429

Blaisdell F.W. (1947) "Development and Hydraulic Design of St. Anthony Falls Stilling Basin", Proc. Journal of Hydraulic Engineering, ASCE

Chanson, H. (2010) "Similitude and Scale Effects of Air Entrainment in Hydraulic Jumps", Journal of Hydraulic Research, Vol. 46, No. 1, PP.35-44

Chow V.T. (1959) "Open-Channel Hydraulics", McGraw Hill Book Co., New York. 
Hitham Abdel Samad, Helal Y. Esam, Ibrahim S.A, and Sobeih M.F, "Minimizing of Scour Downstream ..."

Coleman N.L. (1967), “A Theoretical and Experimental Study of Drag and Lift Forces", International Assoc. Hydraulic Research, 12 Congress, Fort Collins

Edward A. E. (1959)“Hydraulic Energy Dissipators”, Mc-Graw Hill Book Co., INC, New York, Toronto, London.

El-Masry A.A. and Sarhan T.E. (2000) "Minimization of Scour Downstream Heading-Up Structure Using a Single Line of Angle Baffles", Engineering Research Journal, Helwan University, Vol. 69.

El-Masry A.A. (2001) "Minimization of Scour Downstream Heading-Up Structures Using Double Line of Angle Baffles", Proc. of Sixth International Water Technology Conference (IWTC), Alexandria, Egypt.

El-Masry A.A. (2001) "Influence of a Fully Angle Baffled Floor on Scour Behind a Hydraulic Structure", Mansoura Engineering Journal, Vol. 26, No.4.

Froehlich D.C. (1988) "Analysis of Onsite Measurements of Scour at Piers", Proc. ASCE, National Hydraulic Engineering Conference, Colorado

Peterka A.J. (1978), "Hydraulic Design of Stilling Basin and Energy Dissipators", U.S. Dept. of the Interior, Bureau of Reclamation, Denever, Colorado Vischer D.L. and Hager W.H. (1995) "Energy Dissipators", Swiss Federal Institute of Technology, ETH, Zurich, Switzerland.

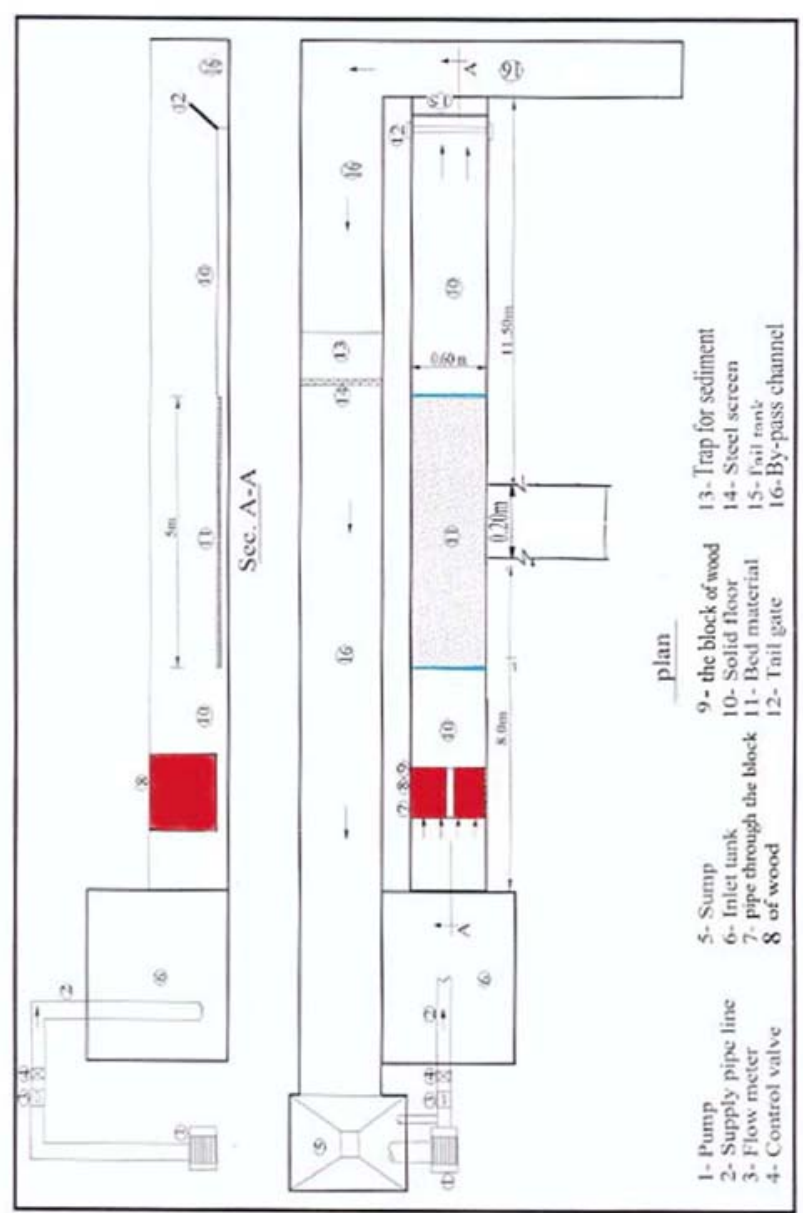

Figure (1) Experimental set-up

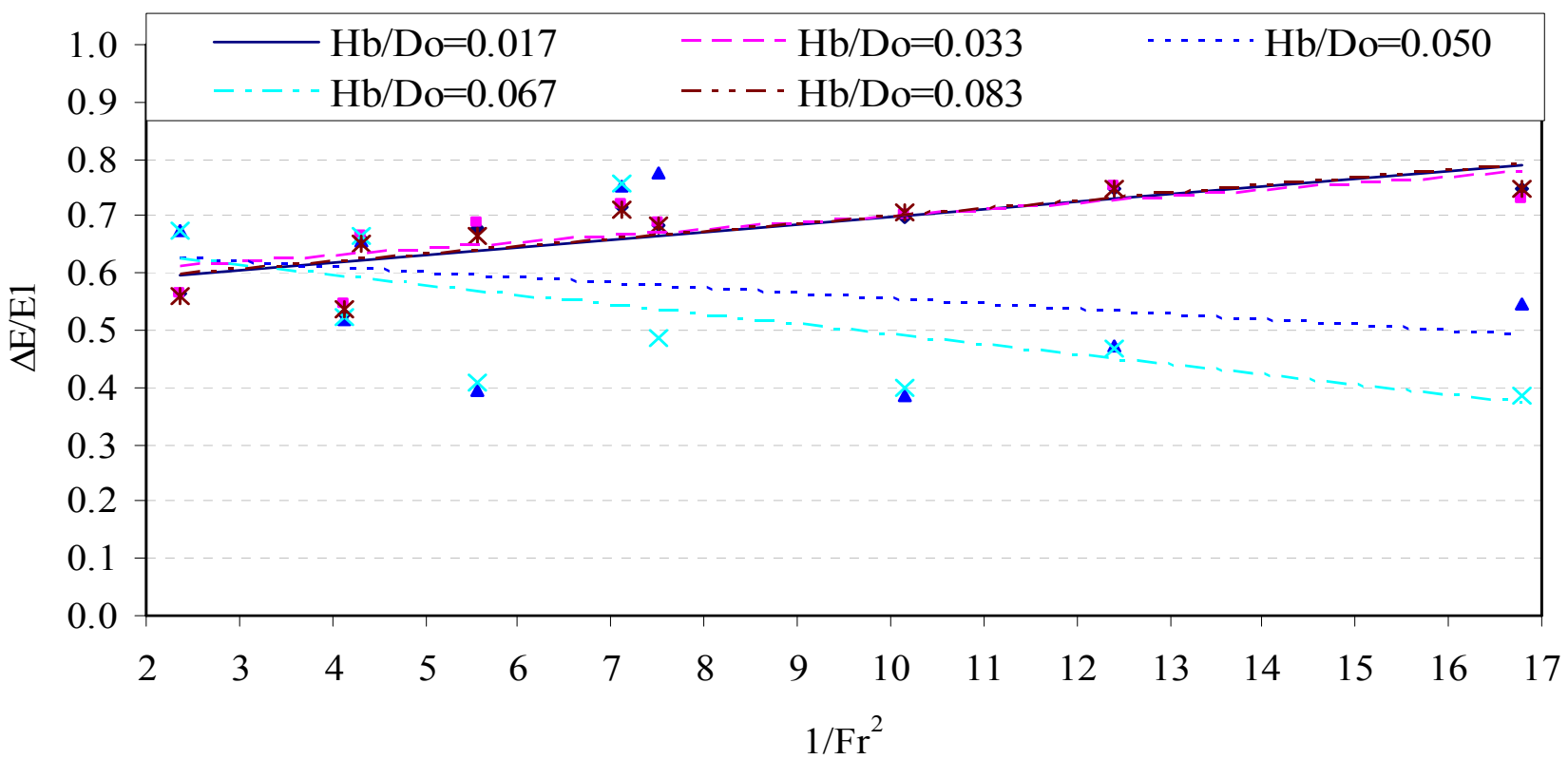

Figure 2: Relation between $\Delta \mathrm{E} / \mathrm{E}_{1}$ and $1 / \mathrm{Fr}^{2}$ at $\mathrm{Lb} / \mathrm{Lf}=0.2$ 
Hitham Abdel Samad, Helal Y. Esam, Ibrahim S.A, and Sobeih M.F, "Minimizing of Scour Downstream ..."

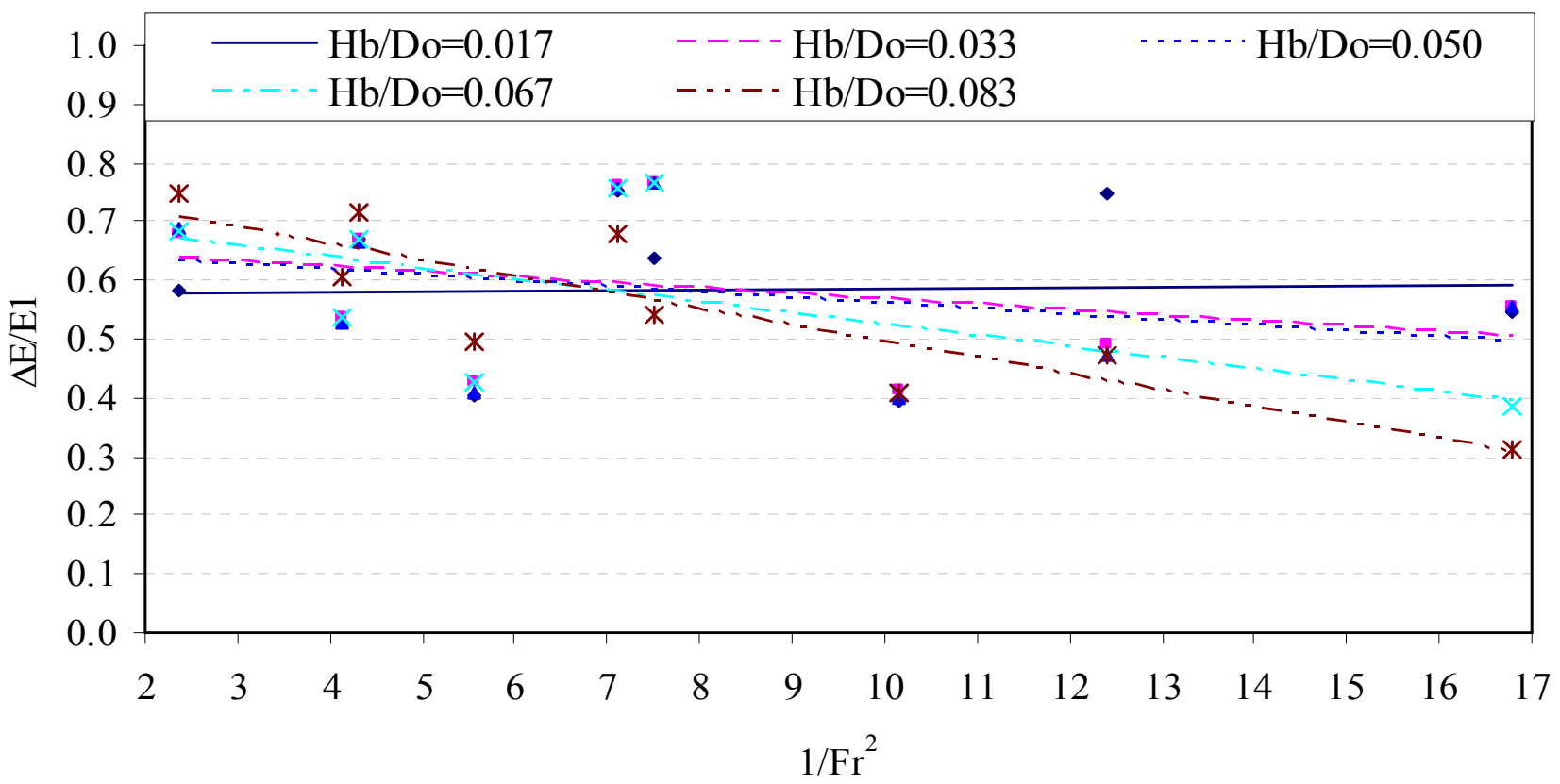

Figure 3: Relation between $\Delta \mathrm{E} / \mathrm{E}_{1}$ and $1 / \mathrm{Fr}^{2}$ at $\mathrm{Lb} / \mathrm{Lf}=0.4$

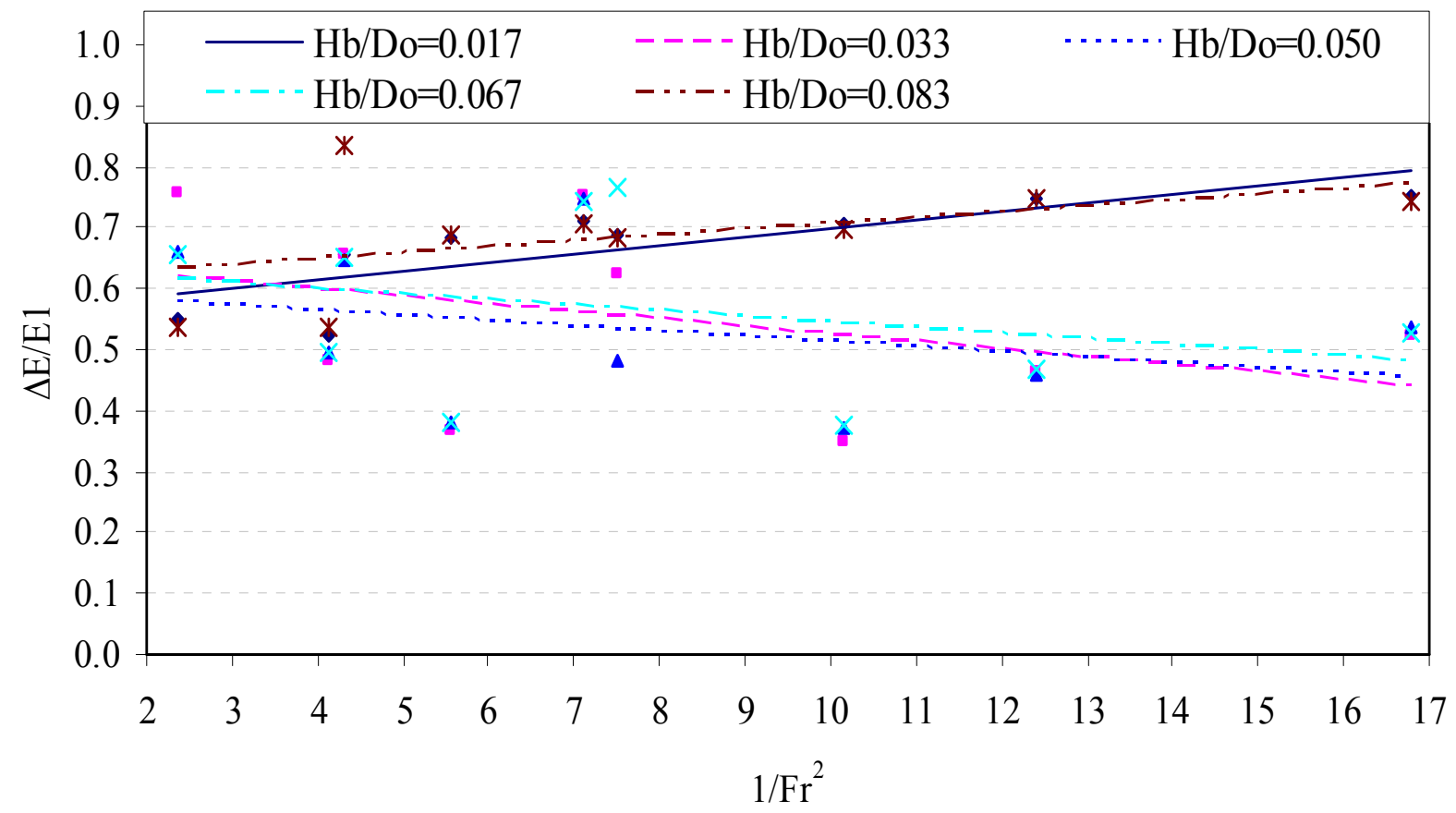

Figure 4: Relation between $\Delta \mathrm{E} / \mathrm{E}_{1}$ and $1 / \mathrm{Fr}^{2}$ at $\mathrm{Lb} / \mathrm{Lf}=0.6$ 
Hitham Abdel Samad, Helal Y. Esam, Ibrahim S.A, and Sobeih M.F, "Minimizing of Scour Downstream ..."

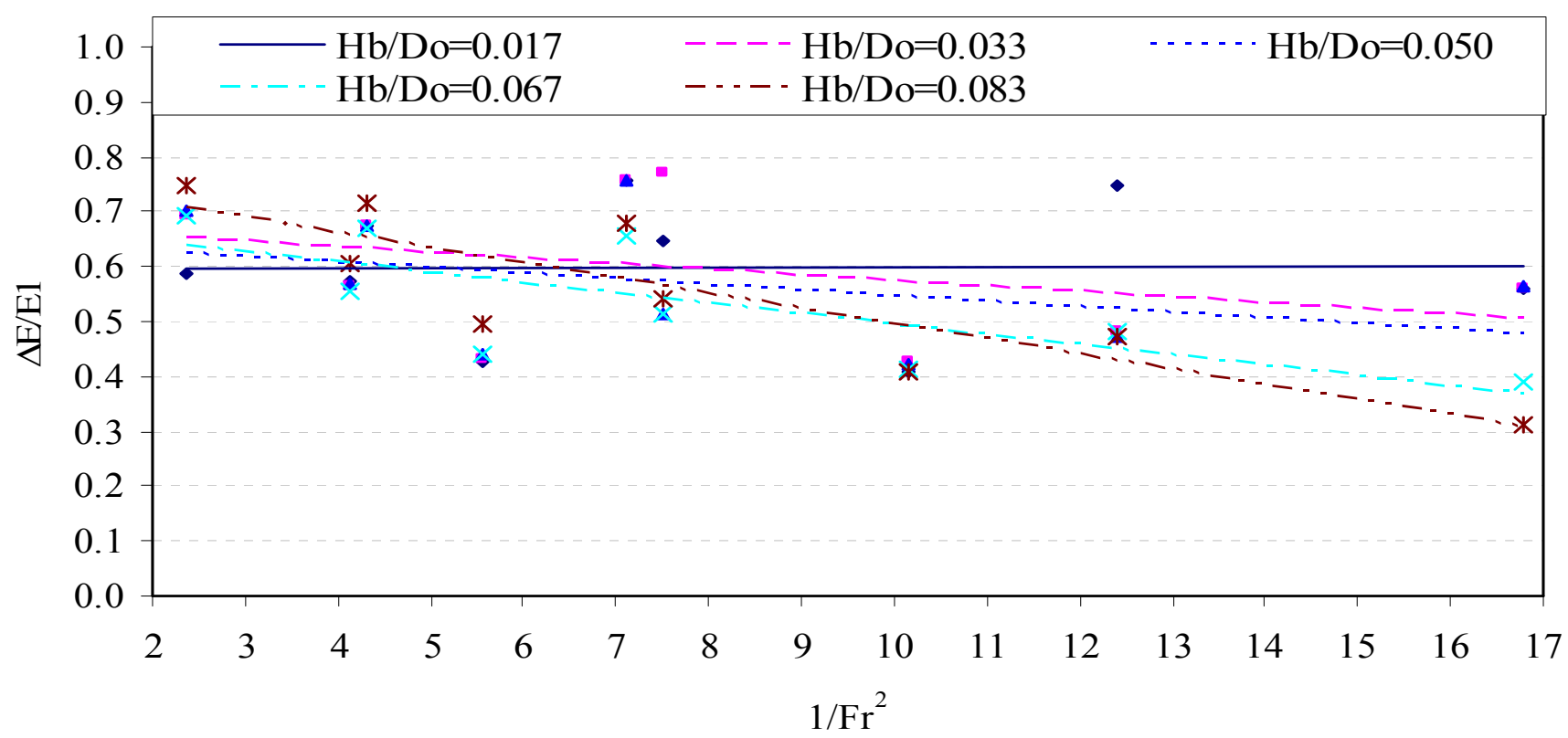

Figure 5: Relation between $\Delta \mathrm{E} / \mathrm{E}_{1}$ and $1 / \mathrm{Fr}^{2}$ at $\mathrm{Lb} / \mathrm{Lf}=0.8$ 
Hitham Abdel Samad, Helal Y. Esam, Ibrahim S.A, and Sobeih M.F, "Minimizing of Scour Downstream ..."
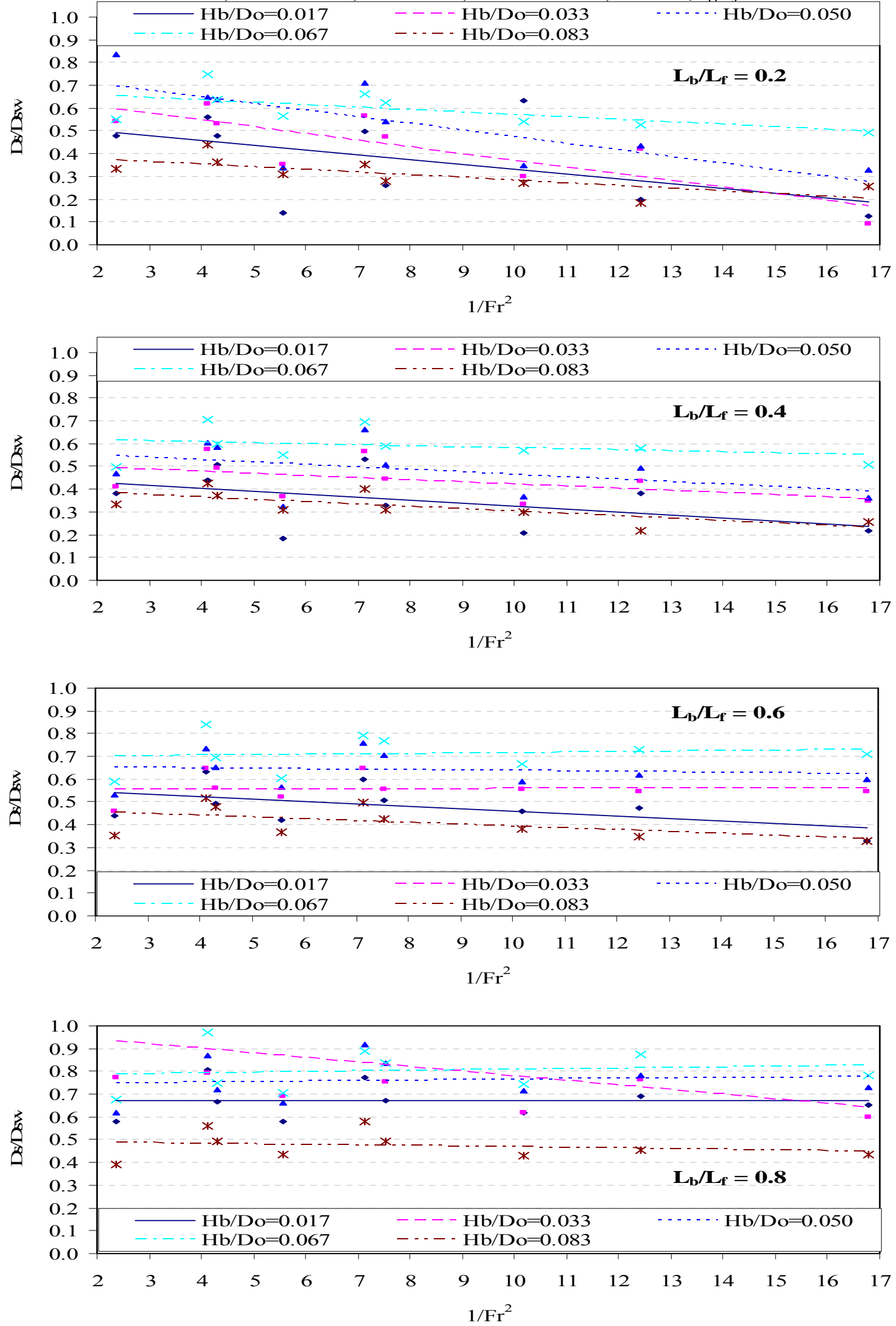

Figure 6: Relation between relative scour depth $\mathrm{D}_{\mathrm{s}} / \mathrm{D}_{\mathrm{sw}}$ and $1 / \mathrm{Fr}^{2}$, for the considered values of sill positions 
Hitham Abdel Samad, Helal Y. Esam, Ibrahim S.A, and Sobeih M.F, "Minimizing of Scour Downstream ..."
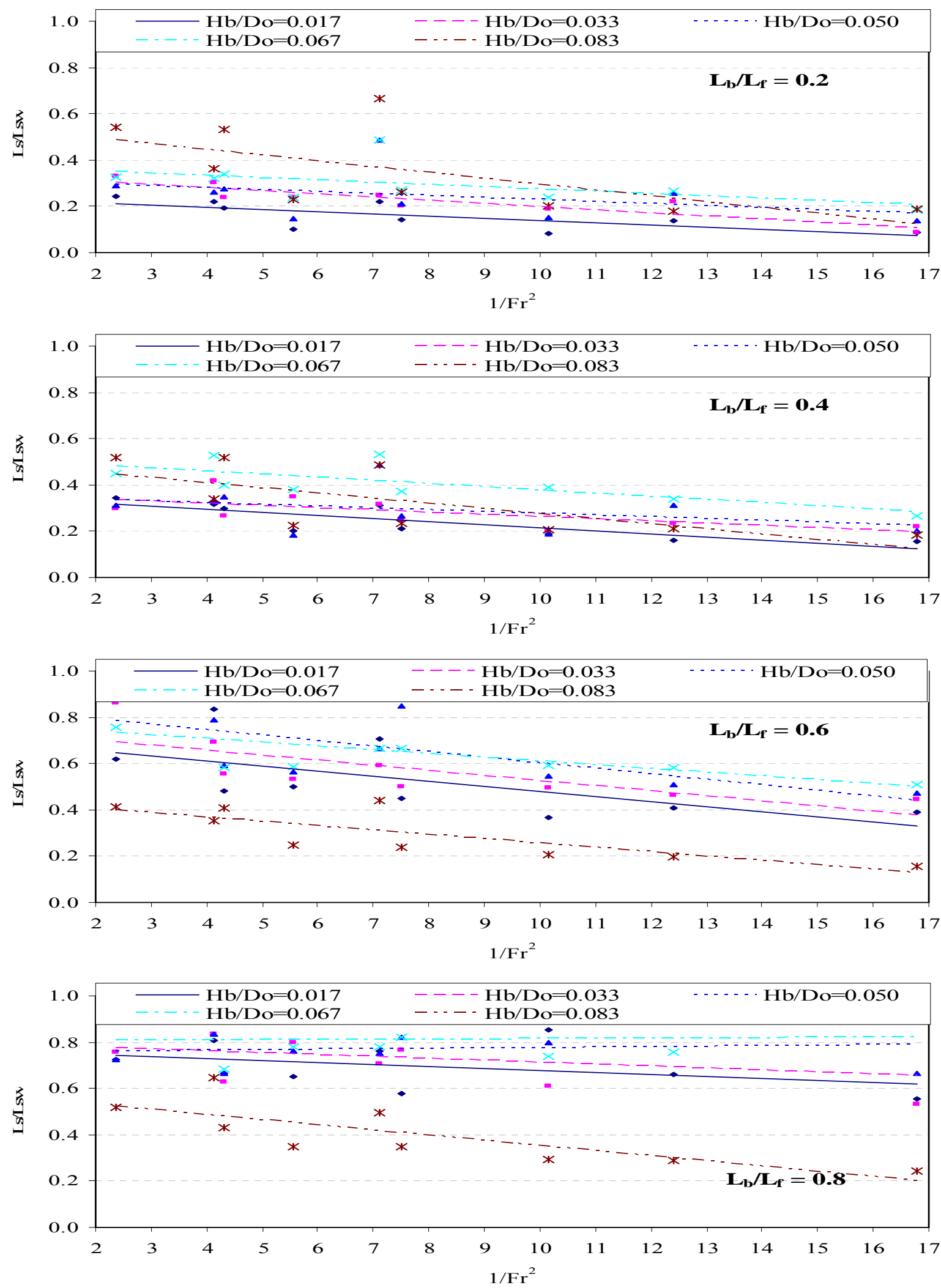

Figure 7: Relation between relative scour length $\mathrm{L}_{\mathrm{s}} / \mathrm{L}_{\mathrm{sw}}$ and $1 / \mathrm{Fr}^{2}$, for the considered values of sill positions 